\title{
Update on Paragangliomas and Pheochromocytomas
}

\author{
Alfred KY LAM \\ Cancer Molecular Pathology, School of Medicine and Menzies Health Institute Queensland, Griffith University, GOLD COAST, QUEENSLAND, AUSTRALIA
}

\begin{abstract}
Genomic studies in the recent decades lead to the identification of new genetic mutations that have been shown to play detrimental roles in the formation of pheochromocytoma or paraganglioma. The majority of these genetic mutations detected affect two major cellular pathways - pseudo hypoxic pathway and kinase signalling pathway. Genetic mutations also resulted in syndromes related to paraganglioma/pheochromocytoma. The classical syndromes comprise - neurofibromatosis, multiple neuroendocrine neoplasia (MEN) (II and III) syndromes and von Hippel-Lindau syndrome. Also, mutations in succinate dehydrogenase genes contribute to the understanding of hereditary paragangliomapheochromocytoma syndromes, Carney's triad and Carney- Stratakis syndrome. Lesions newly known to be associated with the genetic mutations in pheochromocytoma/ paraganglioma include gastrointestinal stromal tumour and renal cell carcinoma. Pathological features, proliferative index, genetic and biochemical parameters could help to predict the malignant potential of paraganglioma and pheochromocytoma. Different predictive systems have been proposed and with the help of immunochemical studies. Pathologist should be aware of the advances in knowledge and contribute to the validation of the pathological features and markers for prediction of malignant potential of this group of tumours.
\end{abstract}

Key Words: Paraganglioma, Pheochromocytoma, Genetics, SDHB, Malignant

\section{GENERAL CONCEPTS UPDATES}

Pheochromocytoma and paragangliomaare neuroendocrine tumours with differentiation of chromaffin cells originated from neural crests. Pheochromocytomas are tumours located in adrenal glands whereas outside the adrenal gland, this group of tumours are labelled paragangliomas. Due to the close relationship with neural tissue, composite lesions were reported both in the adrenal and extraadrenal locations. The other component of the composite tumour could be neuroblastoma, ganglioneuroblastoma, ganglioneuroma or malignant peripheral nerve sheath tumour (1-4).

The classical morphological features of pheochromocytoma or paraganglioma are tumourcellshaving granularcytoplasm with rich vascular networks. S-100 positive sustentacular cells could often be demonstrated. Unusual morphological features like co-existing cortical hyperplasia, vacuolar degeneration of tumour cells, presence of pheochromoblasts (small cells) and calcospherites, melanin pigmentation, cystic and oncocytic changes may be seen (5-9). The clinical and pathological diagnosis of paraganglioma may not be strict forward as they can occur in many different parts of the body. They could mimic other malignancies; negativity for keratins along with positivity for tyrosine hydroxylase and other neuroendocrine marker(s) are useful to confirm the diagnosis. Paragangliomas are sub-grouped based on

(Turk Patoloji Derg 2015, 31(Suppl):105-112)

Received : 14.06.2015 Accepted : 19.06.2015 the locations and properties into 4 groups according to classification by the World Health Organization (10-13).

The first group of paragangliomas are tumours arising from the paraganglia distributed along the parasympathetic nerve in the head, neck and mediastinum. They are tumours in the carotid body, jugulotympanic (middle ear), vagal (base of skull), laryngeal and aortico-pulmonary. Paragangliomas most commonly found in the head/neck region and this group is the most commonly known paraganglioma $(14,15)$.

There are 2 groups of paragangliomas located in ganglia along the sympathetic chain. One group of paragangliomas parallel the distribution of the paravertebral sympathetic chain. Paragangliomas of the retroperitoneum along the aorta including suprarenal, renal hilar and infra-renal sites are the highest in frequency. These paragangliomas may be functionally active with excess secretion of catecholamines (usually norepinephrine) resulting in hypertension. The other group of paragangliomas come from paraganglia that are distributed along the pre- and paravertebral sympathetic chains and the sympathetic nerve fibres innervating the pelvic and retroperitoneal organs. They encompass aorticosympathetic paragangliomas and a subset of "visceralautonomic" paragangliomas. Well-known example of the group is urinary bladder paraganglioma with micturition induced hypertension (14-16). They were also examples noted in intra-thoracic and cervical paravertebral regions.

Correspondence: Alfred LAM

Cancer Molecular Pathology, School of Medicine and Menzies Health

Institute Queensland, Griffith University,

GOLD COAST, QUEENSLAND, AUSTRALIA

E-mail: a.lam@griffith.edu.au Phone: +61 756780718 
The last group of paragangliomas arise outside the usual distribution of sympathetic and parasympathetic paraganglia. They are rare and comprise gangliocytic paraganglioma (small intestine and pancreas), cauda equina paraganglioma, orbital paraganglioma and nasopharyngeal paraganglioma.

\section{UPDATES IN GENETICS}

At one time, this group of tumours were labelled as "10-genes tumours" (17). Starting from around the year 2000 , discovery of the roles of mutations of succinate dehydrogenase (SDH) group of genes revolutionised the concepts of pathogenesis of pheochromocytoma and paraganglioma. The last two decades have witnessed a lot of new discoveries and there are more than more than 20 genetic (mostly germline, but some only sporadic) mutations that have been detected to be associated with the pathogenesis of pheochromocytoma/paraganglioma. The major genetic mutations in this group of tumours listed according to the year of discovery are NF1, RET, VHL, SDHC, SDHD, SDHB, EGLN1, KIF1B, SDHAF2, IDH, SDHA, TMEM 127, MAX, $B A P 1, E P A S 1, F H, M D H 2$ and ATRX respectively (18-35). In addition, the majority of genetic mutations detected play their function in the 2 major cellular pathways. Thus, the genetic mutations causing pheochromocytoma and paragangliomas are grouped into two major clusters (36).

Cluster 1 mutations are involved with the pseudo-hypoxic pathway and with reduced oxidative response. Also, cluster 1 tumours showed a marked increase in vascularization and in the expression of vascular endothelial growth factor (VEGF) and its receptors. VEGF pathway is important in the angiogenesis of many cancers and drugs targeting VEGF pathway is the standard for treatment for many metastatic cancers (37-42). Thus, drugs targeting angiogenesis may be theoretically useful to be on trial on this group of lesions. In addition, some members of the group impair DNA demethylation and this raise the possibility of innovative epigenetic therapies involving demethylation agents for some of these tumours. Examples of the genes in this cluster for the pathogenesis of paraganglioma/ pheochromocytoma comprise VHL, EGLN1, SDHx (SDHC, SDHD, SDHB, SDHAF2, SDHA), IDH, HIF2A, and FH.

Cluster 2 mutations are associated with abnormal activation of kinase signalling pathways and included mutations of RET, NF1, KIF1B $\beta, M A X$ and TMEM127. Examples of the kinase pathways involved are PI3Kinase/AKT, RAS/ RAF/ERK and the mTOR pathway. The mTOR pathway is important in the pathogenesis of many cancers and anticancer agents targeting this pathway is available (43).
Thus, agents targeting mTOR pathway may be investigated for the treatment of some paragangliomas/ pheochromocytomas with cluster 2 gene mutations.

\section{PATHOLOGICAL LESIONS ASSOCIATED WITH PARAGANGLIOMA OR PHEOCHROMOCYTOMA}

An important update of knowledge required for pathologist and clinicians is the spectrum of lesions that could be related to paraganglioma or pheochromocytoma. The presence of syndromes related to phaeochromocytoma or paraganglioma often associated with bilateral tumours (Figure 1).

\section{A. Classical Syndromes}

Classical lesions associated with paragangliomas or pheochromocytomas occur in the hereditary syndromes - neurofibromatosis, multiple neuroendocrine neoplasia (MEN) (II and III) syndromes and von Hippel-Lindau syndrome (44). They are autosomal dominantly inherited diseases. In the settings of neurofibromatosis type I (NF1 gene), pheochromocytoma or paraganglioma could be associated with other neurofibromas, malignant peripheral nerve sheath tumours and gliomas as well as café au lait spots, iris hamartoma and dysplasia of the sphenoid bone. Less commonly, gastrointestinal tumours, glioma or leukaemia may be noted. In multiple neuroendocrine neoplasia II (RET gene), pheochromocytoma could be found with medullary thyroid carcinoma and parathyroid hyperplasia. In multiple neuroendocrine neoplasia III (RET gene), pheochromocytoma could be seen in the settings of medullary thyroid carcinoma, marfanoid habitus

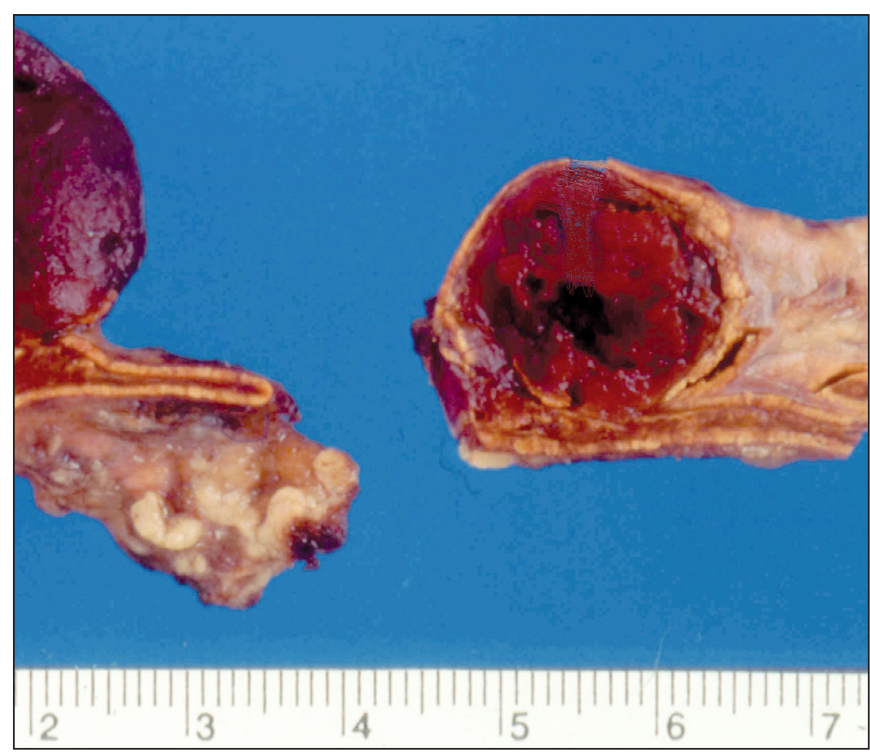

Figure 1: Bilateral pheochromocytoma noted in multiple endocrine neoplasia 2 (MEN 2) syndrome. 
as well as intestinal ganglioneuromas and cutaneous neuromas. Furthermore, in Von Hippel-Lindau syndrome (VHL gene), pheochromocytoma or paraganglioma may be noted in the settings of clear cell renal cell carcinoma and central nervous system (cerebellum and spinal cord) haemangioblastomas.

\section{B. SDH Related Syndromes}

In the last decade, mutations in succinate dehydrogenase $(S D H)$ genes contribute to the hereditary paragangliomapheochromocytoma (PGL-PHEO) syndromes, Carney's triad and Carney- Stratakis syndrome.

\section{B1. Paraganglioma-Pheochromocytoma (PGL-PHEO) Syndromes}

PGL-PHEO syndromes comprise PGL1, PGL2, PGL3, PGL4 and PGL5 (36,44-48). PGL1 consists of pheochromocytoma or head \&neck paraganglioma and relates to mutation in SDHD gene. The lesions noted in this condition also include gastrointestinal stromal tumour (GIST) and pituitary adenoma. PGL2 is related to mutation in SDHAF2 gene and consists of head \& neck paraganglioma without other known lesions. PGL3 is associated with mutation with SDHC gene and characterized by head \& neck paraganglioma and gastrointestinal stromal tumour PGL4 is due to the mutation in the SDHB gene. The disease could present as pheochromocytoma or head \& neck paraganglioma as well as the presence of papillary thyroid carcinoma, breast cancer, gastrointestinal stromal tumour and renal cell carcinoma. The type of renal cell carcinoma is a tumour of specific histological features and is now currently labelled as $S D H B$ negative renal cell carcinoma (48). PGL5 is noted with mutation of SDHA gene. The disease could have paraganglioma and gastrointestinal stromal tumour.

In other words, the most common lesion noted in the PGL-PHEO syndrome is gastrointestinal stromal tumour (49). Pathologists should take notice if a GIST is detected in paediatric or young populations and without c-kit or PDGFR alpha (platelet-derived growth factor receptor alpha) mutation typically noted in majority of GIST. The GIST in this setting is likely to be having epitheloid morphology and have higher incidence of lymph node metastases. The GIST will not be responsive to standard therapy for GIST - Imatinib (tyrosine-kinase inhibitor)

\section{B2. Carney-Stratakis Syndrome (Carney-Stratakis Dyad) and Carney Triad}

Carney-Stratakis syndrome (Carney dyad) is an autosomal dominant syndrome associated with mutations in $S D H B$,
$S D H C$, and $S D H D$ (50). This syndrome is characterised by association of paragangliomas and gastrointestinal stromal tumour. In Carney's triad, paragangliomas are noted to be associated with gastrointestinal stromal tumour as well as pulmonary chondroma. Also, adrenal cortical adenoma, oesophageal leiomyoma and pheochromoctyoma may be noted (51). Hyper-methylation of the promotor region of $S D H C$ was recently reported to be responsible for the syndrome (52). The GIST is of similar pathological characteristics noted in PGL-PHEO syndromes.

It is worth noting that Carney-Stratakis dyad and Carney triad are different entirely from Carney complex in terms of pathogenesis (53). Carney complex is an autosomal dominant caused by mutations in the PRKAR1A (protein kinase $\mathrm{A}$, regulatory subunit, type 1 , alpha) gene on chromosome 17q23-q24 or other genes on chromosome $2 \mathrm{p} 16$. The complex has myxomas of the heart and skin, hyperpigmentation of skin and pituitary adenoma. The only feature in common in SDH related syndromes is the presence of pituitary adenoma.

\section{UPDATES ON TERMINOLOGY}

Pheochromocytomas have been called the "10\% tumour" as many of the characteristics of the tumour could be accounted about ten percent of the time (54). These features may include approximately $10 \%$ are bilateral (i.e. in both adrenal glands), $10 \%$ are found in children, $10 \%$ are genetic (i.e. inherited), $10 \%$ are malignant or recurrence, and $10 \%$ are found outside the adrenal gland (paraganglioma). In addition, approximately $10 \%$ of these tumours are found after the patient has a stroke and $10 \%$ noted to be associated with MEN syndromes. The "10\% features" are noted to useful to arise awareness and remember the characteristics of this group of tumours. However, with the recent advances in knowledge about the tumours, we noted that these $10 \%$ features are no longer accurate.

The two $10 \%$ features that should definitely be deleted on the list are namely - " $10 \%$ extra-adrenal" and " $10 \%$ genetic". Many of the larger series had shown that paraganglioma could occur in different parts of the body and are found in higher prevalence than $10 \%$ extra-adrenal. The true prevalence of extra-adrenal lesions (paragangliomas) should be around 30 to $40 \%$ (14). Also, it is now clear from the genetic studies that up to $40 \%$ of this group of tumours are either inherited or having known genetic susceptibility (36).

\section{PREDICATION OF MALIGNANT POTENTIAL}

The prediction of malignant potential for endocrine tumours is always a problem for pathologists and clinicians. As in the case for other endocrine tumours, there is no definite 
histological feature that can predict the clinical behaviour of both paraganglioma and pheochromocytoma before metastases occur. In 2002, PASS (Pheochromocytoma of the Adrenal gland Scaled Score) have been developed by Thompson after review of 100 cases of pheochromocytoma (55). PASS is based on a set of 12 histological features. Benign pheochromocytoma has a score of less than 4 and malignant pheochromocytoma has a PASS score higher than 6. Patients with a PASS $>4$ should be followed closely for recurrence. The drawbacks of using PASS are the score is based purely on histological features and is only for pheochromocytoma. Also, the assessment of 12 histological features is a complex and time consuming task. The prognostic values of PASS have been tested by different research groups and usefulness of PASS has been questioned $(56,57)$.

In 2005, Kimura and colleagues from Japan proposed another system for assessment of malignant potential of this group of tumours based on 146 pheochromocytoma and paraganglioma (58). The system was refined in 2014 based on a total of 163 tumours, including 40 metastatic tumours, collected by the Pheochromocytoma Study Group in Japan (PHEO-J) (59). The system is called grading system for adrenal pheochromocytoma and paraganglioma (GAPP). The tumours were classified as well (score $=0-2$ ), moderately (score $=3-6$ ), and poorly differentiated (score =7-10) types according to their scores. The differentiation of the pheochromocytoma appears to be correlated with potential for metastases and survival rates. Patients with poorly-differentiated pheochromocytoma are malignant and reported to have $0 \%$ survival rate. The system is yet to be validated by other researchers in different groups.

GAPP was based on 4 histological features (histological pattern, cellularity, comedo-type necrosis, capsular/ vascular invasion), proliferative index (Ki-67) and hormones secreted (biochemical phenotype) by the pheochromocytoma/paraganglioma. The GAPP system has the merits on assessing potential reproducible histological parameters. It also takes into account of commonly used parameter, Ki-67 proliferative index. The Ki-67 nuclear antigen has been associated with more aggressive cancers in different cancers. A Ki-67 index $>3 \%$ is considered a useful parameter predicting malignant potential (60). One potential difficulty in using the GAPP is the range of Ki67 index adopted is very narrow. The score is: very few cells positive (score $=0) ; 1-3 \%$ positive $($ score $=1)$ and $>3 \%$ positive $(=2)$.

GAPP takes into account of biochemical properties of paraganglioma or pheochromocytoma. Tumours with norepinephrine (noradrenaline) secretion are given higher score than non-functional tumours or tumours secreting epinephrine (adrenaline). It is worth noting that pheochromocytoma mainly produce adrenaline, while functional paraganglioma secrete noradrenaline. Malignant tumours have been shown to secrete predominantly noradrenaline, but due to less-differentiated catecholamine biosynthetic pathway, they may often produce mainly or exclusively dopamine (60). Therefore, the presence of large predominantly noradrenaline-producing paragangliomas and increased levels of plasma dopamine or its metabolite methoxytyramine may suggest malignancy. It is worth noting that malignancy in this group of tumours is generally associated to very high plasma levels of chromogrannin (61).

Beside histological factors, larger tumour $(>5 \mathrm{~cm})$ appears to be carry a higher risk of malignancy (60-62). The survival rate may depend upon sites of metastatic lesions. Also, patients with liver or lung metastases tend to have a poorer survival rates than patients with isolated bone lesions (60).

Different molecular markers have been proposed to affect the survival of patients with pheochromocytoma or paragangliomas (60). For the genes that have been discovered in the pathogenesis of pheochromocytoma/paraganglioma in the last couple years, SDHB and FH mutations have been associated with a high malignant potential in pheochromocytoma/ paraganglioma harbouring the genes. In particular, SDHB mutation has been studied in depth in this group of tumours with immunohistochemistry using commercially available antibody (Figure 2A,B). The Japanese group who proposed the GAPP system has also taken SDHB expression as a prognostic parameter (59).

For tumours that are negative for SDHB protein, it is likely that one of the few SDH genes have been mutated. SDHA protein loss could also be tested by immunohistochemistry. Therefore, SDHB immunohistochemistry could be performed to guide genetic testing in pheochromocytoma/ paraganglioma. The negative staining may be difficult to be assessed probably. Nevertheless, the reproductively of the use of SDHB/SDHA in pheochromocytoma/paraganglioma has been validated by multicentre inter-observer variation analysis in Europe (63).

Micro-RNAs are known to be affected many target genes and are important in pathogenesis and predication of clinical behaviour of different cancers (64-70). Wholeexome sequencing analysis of pheochromocytoma/ paraganglioma has been presented (71). A group of few micro-RNAs related to the genomic results was also noted to be able to predict the behaviour of this group of tumour (71,72). 

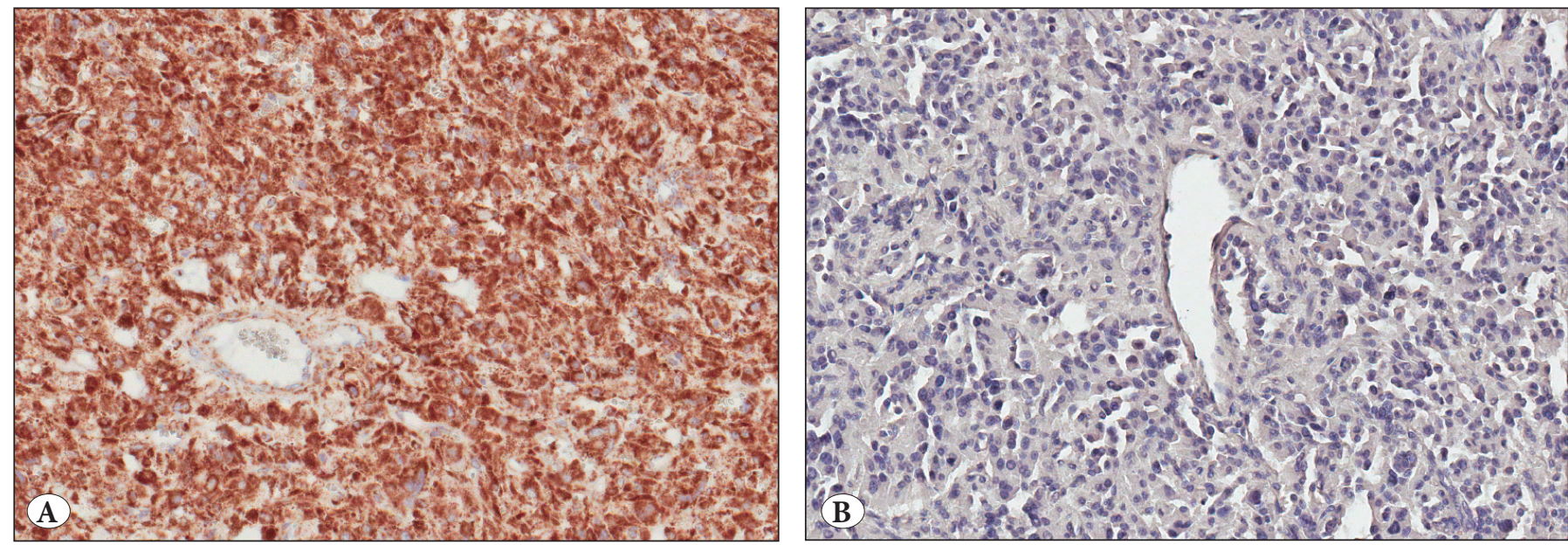

Figure 2: The role of SDHB immunohistochemistry. A) Paraganglioma which is positive for SDHB protein expression (Immunohistochemistry; $\mathrm{x}$ 14); B) Paraganglioma which is negative for SDHB protein expression (Immunohistochemistry; $\mathrm{x} 14$ ). Genetic testing for SDHx genes should be performed in such case.

\section{CONCLUSION REMARKS}

It is clear that profound knowledge have been gain in the understanding of pathogenesis and nature of diseases associated with pheochromocytoma/paraganglioma. The findings may help in development and optimization of management strategies for patients with this group of tumours. Pathologist should aware of the updates in knowledge, contribute to validation of the pathological features and markers for prediction of malignant potential of this group of tumours.

\section{CONFLICT OF INTEREST}

The author has declared no conflict of interest.

\section{REFERENCES}

1. Lam KY, Lo CY. Composite pheochromocytoma-ganglioneuroma of the adrenal gland: An uncommon entity with distinctive clinicopathologic features. Endocr Pathol. 1999;10: 343-52.

2. Lam KY, Loong F, Shek TWH, ChuSM. Composite paragangliomaganglioneuroma of the urinary bladder: A cliniopathologic, immunohistochemical, and ultrastructural study of a case and review of the literature. Endocr Pathol. 1998;9: 363-73.

3. Lam KY. The pathology of adrenal tumors. Cancer Journal. 1994;7:181-87.

4. Ch'ng ES, Hoshida Y, Iizuka N, Morii E, Ikeda JI, Yamamoto A, Tomita Y, Hanasaki H, Katsuya T, Maeda K, Ohishi M, Rakugi H, Ogihara T, Aozasa K. Composite malignant pheochromocytoma with malignant peripheral nerve sheath tumour: A case with 28 years of tumour-bearing history. Histopathology. 2007;51:420-22.

5. Lam KY, Chan ACL, Wong WM, Lam KSL. A review of clinicopathologic features of pheochromocytomas in Hong Kong Chinese. Eur J Surg Oncol. 1993;19:421-27.
6. Bellezza G, Giansanti M, Cavaliere A, Sidoni A. Pigmented "black" pheochromocytoma of the adrenal gland: A case report and review of the literature. Arch Pathol Lab Med. 2004;128:e12528.

7. Lamovec J, Frković-Grazio S, Bracko M. Nonsporadic cases and unusual morphological features in pheochromocytoma and paraganglioma. Arch Pathol Lab Med. 1998;122:63-8.

8. Kasem K, Lam AK. Adrenal oncocytic phaeochromocytoma with putative adverse histologic features: A unique case report and review of the literature. Endocr Pathol. 2014; 25:416-21.

9. Erem C, Kocak M, Onder Ersoz H, Ersoz S, Yucel Y. Epinephrinesecreting cystic pheochromocytoma presenting with an incidental adrenal mass: A case report and a review of the literature. Endocrine. 2005;28:225-30.

10. Kimura N, Chetty R, Capella C, Young WF, Koch CA, Lam KY, DeLellis RA, Kawashima A, Komminoth P, Tischler AS. Extraadrenal paraganglioma: Carotid body, jugulotympanic, vagal laryngeal aortico-pulmonary. In: DeLellis RA, Lloyd RV, Hitz PU, Eng C, editors. World Health Organization classification of tumors, Vol: 8, Pathology and genetics, tumors of endocrine organs, Lyon:WHO Press;2004. 159-61.

11. Tischler AS, Komminoth P, Kimura N, Young WF, Chetty R, Albores-Saavedra J, Kleihues P. Extra-adrenal paraganglioma: Gangliocytic, cauda equine, orbital nasopharyngeal. In: DeLellis RA, Lloyd RV, Hitz PU, Eng C, editors. World Health Organization classification of tumors, Vol:8, Pathology and genetics, tumors of endocrine organs, WHO Press;2004.162-63.

12. Kimura N, Capella C, De Krijger RR, Thompson LDR, Lam KY, Komminoth P, Tischler AS, Young WF. Extra-adrenal sympathetic paraganglioma: Superior and inferior paraaortic paraganglioma. In: DeLellis RA, Lloyd RV, Hitz PU, Eng C, editors. World Health Organization classification of tumors, Vol:8, Pathology and Genetics, Tumors of Endocrine Organs,WHO Press;2004.164-65. 
13. Tischler AS, Komminoth P. Extra-adrenal sympathetic paraganglioma: Cervical paravertebral, intrathoracic and urinary bladder. In: DeLellis RA, Lloyd RV, Hitz PU, Eng C, editors. World Health Organization classification of tumors, Vol:8, pathology and genetics, tumors of endocrine organs, WHO Press; 2004. 165-66.

14. Lam KY, Lo CY, Wat NM, Luk JM, Lam KS. The clinicopathological features and importance of $\mathrm{p} 53, \mathrm{Rb}$, and $\mathrm{mdm} 2$ expression in phaeochromocytomas and paragangliomas. J Clin Pathol. 2001;54:443-48.

15. Lam KY, Chan ACL. Paragangliomas: A comparative clinical, histologic and immunohistochemical study. Int J Surg Pathol. 1993;1:111-16.

16. Lam KY, Chan ACL. Paraganglioma of urinary bladder: An immunohistochemical study and report of an unusual association with intestinal carcinoid. Aust NZ J Surg. 1993;63:740-45.

17. Gimenez-Roqueplo AP, Dahia PL, Robledo M. An update on the genetics of paraganglioma, pheochromocytoma, and associated hereditary syndromes. Horm Metab Res. 2012;44:328-33.

18. Xu W, Mulligan LM, Ponder MA, Liu L, Smith BA, Mathew CG, Ponder BA. Loss of NF1 alleles in phaeochromocytomas from patients with type neurofibromatosis. Genes Chromosomes Cancer. 1992;4:337-42.

19. Mulligan LM, Kwok JB, Healey CS, Elsdon MJ, Eng C, Gardner E, Love DR, MoleSE, Moore JK, Papi L. Germ-line mutations of the RET proto-oncogene inmultiple endocrine neoplasia type 2A. Nature. 1993;363:458-60.

20. Brauch H, Kishida T, Glavac D, Chen F, Pausch F, Höfler H, Latif F, Lerman MI,Zbar B, Neumann HP. Von Hippel-Lindau (VHL) disease with pheochromocytoma in the Black Forest region of Germany: Evidence for a founder effect. Hum Genet. 1995;95:551-56.

21. Niemann S, Müller U. Mutations in SDHC cause autosomal dominant paraganglioma, type 3. Nat Genet. 2000;26:268-70.

22. Baysal BE, Ferrell RE, Willett-Brozick JE, Lawrence EC, Myssiorek D, Bosch A, van der Mey A, Taschner PE, Rubinstein WS, Myers EN, Richard CW 3rd, CornelisseCJ, Devilee P, Devlin B. Mutations in SDHD, a mitochondrial complex II gene, inhereditary paraganglioma. Science. 2000;287:848-51.

23. Astuti D, Latif F, Dallol A, Dahia PL, Douglas F, George E, Sköldberg F, Husebye ES, Eng C, Maher ER. Gene mutations in the succinate dehydrogenase subunit SDHB cause susceptibility to familial pheochromocytoma and to familialparaganglioma. Am J Hum Genet. 2001;69:49-54.

24. Hao HX, Khalimonchuk O, Schraders M, Dephoure N, Bayley JP, Kunst H, DevileeP, Cremers CW, Schiffman JD, Bentz BG, Gygi SP, Winge DR, Kremer H, Rutter J.SDH5, a gene required for flavination of succinate dehydrogenase, is mutated in paraganglioma. Science. 2009;325:1139-42.

25. Burnichon N, Brière JJ, Libé R, Vescovo L, Rivière J, Tissier F, Jouanno E,Jeunemaitre X, Bénit P, Tzagoloff A, Rustin P, Bertherat J, Favier J,Gimenez-Roqueplo AP. SDHA is a tumor suppressor gene causing paraganglioma. Hum Mol Genet. 2010;19:3011-20.
26. Ladroue C, Carcenac R, Leporrier M, Gad S, Le Hello C, GalateauSalle F, Feunteun J, Pouysségur J, Richard S, Gardie B. PHD2 mutation and congenital erythrocytosis with paraganglioma. N Engl J Med. 2008;359:2685-92.

27. Schlisio S, Kenchappa RS, Vredeveld LC, George RE, Stewart R, Greulich H, Shahriari K, Nguyen NV, Pigny P, Dahia PL, Pomeroy SL, Maris JM, Look AT, Meyerson M, Peeper DS, Carter BD, Kaelin WG Jr. The kinesin KIF1Bbeta acts downstreamfrom EglN3 to induce apoptosis and is a potential 1p36 tumor suppressor. Genes Dev. 2008;22:884-93.

28. Gaal J, Burnichon N, KorpershoekE, Roncelin I, Bertherat J, Plouin PF, de Krijger RR, Gimenez-Roqueplo AP, Dinjens WN. Isocitrate dehydrogenase mutationsare rare in pheochromocytomas and paragangliomas. J Clin Endocrinol Metab. 2010;95:1274-78.

29. Qin Y, Yao L, King EE, Buddavarapu K, Lenci RE, Chocron ES, Lechleiter JD,Sass M, Aronin N, Schiavi F, Boaretto F, Opocher G, Toledo RA, Toledo SP, Stiles C, Aguiar RC, Dahia PL. Germline mutations in TMEM127 confer susceptibility topheochromocytoma. Nat Genet. 2010;42:229-33.

30. Comino-Méndez I, FJ Gracia-Aznárez, Schiavi F, Landa I, Leandro-García LJ, Latvian R, Honore E, Ramos-Medina R, Caronia D, Pita G, Gómez-Grana A, CubasAA, Inglada-Pérez L, Maliszewska A, Taschin E, Bobisse S, Pica G, Loli P,Washing Hernández R, Diaz JA, Gomez-Morales M, Gonzalez-Neira A, Roncador G,Rodriguez-Antona C, Benitez J, M Mannelli, Opocher G, Robledo M, Cascón A. ExomeIdentifies sequencing MAX mutations as a cause of hereditary pheochromocytoma. Nat Genet. 2011;43:663-67.

31. Wadt K, Choi J, Chung JY, Kiilgaard J, Heegaard S, Drzewiecki KT, Trent JM,Hewitt SM, Hayward NK, Gerdes AM, Brown KM. A cryptic BAP1 splice mutation in afamily with uveal and cutaneous melanoma, and paraganglioma. Pigment Cell Melanoma Res. 2012;25:815-18.

32. Zhuang Z, Yang C, Lorenzo F, Merino M, Fojo T, Kebebew E, Popovic V, StratakisCA, Prchal JT, Pacak K. Somatic HIF2A gainof-function mutations in paraganglioma with polycythemia. $\mathrm{N}$ Engl J Med. 2012;367:922-30.

33. Letouzé E, Martinelli C, Loriot C, Burnichon N, Abermil N, Ottolenghi C, JaninM, Menara M, Nguyen AT, Benit P, Buffet A, Marcaillou C, Bertherat J, Amar L,Rustin P, De Reyniès A, Gimenez-Roqueplo AP, Favier J. SDH mutations establish a hypermethylator phenotype in paraganglioma. Cancer Cell. 2013;23:739-52.

34. Cascón A, Comino-Méndez I, Currás-Freixes M, de Cubas AA, Contreras L, RichterS, Peitzsch M, Mancikova V, Inglada-Pérez L, Pérez-Barrios A, Calatayud M, AzrielS, Villar-Vicente R, Aller J, Setién F, Moran S, Garcia JF, Río-Machín A, LetónR, GómezGraña Á, Apellániz-Ruiz M, Roncador G, Esteller M, RodríguezAntona C,Satrústegui J, Eisenhofer G, Urioste M, Robledo M. Whole-Exome Sequencing Identifies $\mathrm{MDH} 2$ as a New familial Paraganglioma Gene. J Natl Cancer Inst. 2015;107: pii: djv053.

35. Fishbein L, Khare S, Wubbenhorst B, DeSloover D, D’Andrea K, Merrill S, Cho NW, Greenberg RA, Else T, Montone K, LiVolsi V, Fraker D, Daber R, Cohen DL, Nathanson KL. Whole-exome sequencing identifies somatic ATRX mutations in pheochromocytomas and paragangliomas. Nat Commun. 2015;6:6140. 
36. Dahia PL. Pheochromocytoma and paraganglioma pathogenesis: Learning from genetic heterogeneity. Nat Rev Cancer. 2014;14:108-19.

37. Xu WW, Li B, Lam AK, Tsao SW, Law SY, Chan KW, Yuan QJ, Cheung AL. Targeting VEGFR1- and VEGFR2-expressing nontumor cells is essential for esophageal cancer therapy. Oncotarget. 2015;6:1790-805.

38. Salajegheh A, Pakneshan S, Rahman A, Dolan-Evans E, Zhang S, Kwong E, Gopalan V, Lo CY, Smith RA, Lam AK. Co-regulatory potential of vascular endothelial growth factor-A and vascular endothelial growth factor-C in thyroid carcinoma. Hum Pathol. 2013;44:2204-12.

39. Salajegheh A, Smith RA, Kasem K, Gopalan V, Nassiri MR, William R, Lam AK. Single nucleotide polymorphisms and mRNA expression of VEGF-A in papillary thyroid carcinoma: Potential markers for aggressive phenotypes. Eur J Surg Oncol. 2011;37: 93-9.

40. Yu XM, Lo CY, Lam AK, Leung P, Luk JM. Serum vascular endothelial growth factor $\mathrm{C}$ correlates with lymph node metastases and high-risk tumor profiles in papillary thyroid carcinoma. Ann Surg. 2008;247:483-89.

41. Yu XM, Lo CY, Lam AK, Lang BH, Leung P, Luk JM. The potential clinical relevance of serum vascular endothelial growth factor (VEGF) and VEGF-C in recurrent papillary thyroid carcinoma. Surgery. 2008;144:934-40.

42. Yu XM, Lo CY, Chan WF, Lam KY, Leung P, Luk JM. Increased expression of vascular endothelial growth factor $\mathrm{C}$ in papillary thyroid carcinoma correlates with cervical lymph node metastases. Clin Cancer Res. 2005;11:8063-69.

43. Alqurashi N, Gopalan V, Smith RA, Lam AK. Clinical impacts of mammalian target of rapamycin expression in human colorectal cancers. Hum Pathol. 2013;44:2089-96.

44. Welander J, Söderkvist P, Gimm O. Genetics and clinical characteristics of hereditary pheochromocytomas and paragangliomas. Endocr Relat Cancer. 2011;18:R253-76.

45. Müller U. Pathological mechanisms and parent-of-origin effects in hereditary paraganglioma/pheochromocytoma (PGL/PCC). Neurogenetics. 2011;12:175-81.

46. Chetty R. Familial paraganglioma syndromes. J Clin Pathol. 2010;63:488-91.

47. Gill AJ. Succinate dehydrogenase (SDH) and mitochondrial driven neoplasia. Pathology. 2012;44:285-92.

48. Williamson SR, Eble JN, Amin MB, Gupta NS, Smith SC, Sholl LM, Montironi R, Hirsch MS, Hornick JL. Succinate dehydrogenasedeficient renal cell carcinoma:detailed characterization of 11 tumors defining a unique subtype of renal cell carcinoma. Mod Pathol. 2015;28:80-94.

49. Wang YM, Gu ML, Ji F. Succinate dehydrogenase-deficient gastrointestinal stromal tumors. World J Gastroenterol. 2015;21:2303-14.

50. McWhinney SR, Pasini B, Stratakis CA; International Carney Triad andCarney-Stratakis Syndrome Consortium. Familial gastrointestinal stromal tumors and germ-line mutations. N Engl J Med. 2007;357:1054-56.
51. Stratakis CA. New genes and/or molecular pathways associated with adrenal hyperplasias and related adrenocortical tumors. Mol Cell Endocrinol. 2009;300:152-57.

52. Haller F, Moskalev EA, Faucz FR, Barthelmeß S, Wiemann S, Bieg M, Assie G, Bertherat J, Schaefer IM, Otto C, Rattenberry E, Maher ER, Ströbel P, Werner M, Carney JA, Hartmann A, Stratakis CA, Agaimy A. Aberrant DNA hypermethylation of SDHC: A novel mechanism of tumor development in Carney triad. Endocr Relat Cancer. 2014;21:567-77.

53. Salpea P, Stratakis CA. Carney complex and McCune Albright syndrome: An overview of clinical manifestations and human molecular genetics. Mol Cell Endocrinol. 2014;386:85-91.

54. Pacak K, Del Rivero J. Pheochromocytoma. 2013 Jun 10. In: De Groot LJ, Beck-Peccoz P, Chrousos G, Dungan K, Grossman A, Hershman JM, Koch C, McLachlan R, New M, Rebar R, Singer F, Vinik A, Weickert MO, editors. Endotext [Internet]. South Dartmouth (MA): MDText.com, Inc.; 2000 sz

55. Thompson LD. Pheochromocytoma of the Adrenal gland Scaled Score (PASS) to separate benign from malignant neoplasms: A clinicopathologic and immunophenotypic study of 100 cases. Am J Surg Pathol. 2002;26:551-66.

56. Agarwal A, Mehrotra PK, Jain M, Gupta SK, Mishra A, Chand G, Agarwal G, Verma AK, Mishra SK, Singh U. Size of the tumor and pheochromocytoma of the adrenal gland scaled score (PASS): Can they predict malignancy? World J Surg. 2010;34:3022-28.

57. Mlika M, Kourda N, Zorgati MM, Bahri S, Ben Ammar S, Zermani R. Prognostic value of Pheochromocytoma of the Adrenal Gland Scaled Score (Pass score) tests to separate benign from malignant neoplasms. Tunis Med. 2013;91:209-15.

58. Kimura N, Watanabe T, Noshiro T, Shizawa S and Miura Y. Histological grading of adrenal and extra-adrenal pheochromocytomas and relationship to prognosis: A clinicopathological analysis of 116 adrenal pheochromocytomas and 30 extra-adrenal sympathetic paragangliomas including 38 malignant tumors. Endocr Pathol. 2005;16:23-32.

59. Kimura N, Takayanagi R, Takizawa N, Itagaki E, Katabami T, Kakoi N, Rakugi H, Ikeda Y, Tanabe A, Nigawara T, Ito S, Kimura I, Naruse M; Phaeochromocytoma Study Group in Japan. Pathological grading for predicting metastasis in phaeochromocytoma and paraganglioma. Endocr Relat Cancer. 2014;21:405-14.

60. Parenti G, Zampetti B, Rapizzi E, Ercolino T, Giachè V, Mannelli M. Updated and new perspectives on diagnosis, prognosis, and therapy of malignant pheochromocytoma/paraganglioma. J Oncol. 2012;2012:872713.

61. Szalat A, Fraenkel M, Doviner V, Salmon A, Gross DJ. Malignant pheochromocytoma: Predictive factors of malignancy and clinical course in 16 patients at a single tertiary medical center. Endocrine. 2011;39:160-66.

62. de Wailly P, Oragano L, Radé F, Beaulieu A, Arnault V, Levillain P, Kraimps JL. Malignant pheochromocytoma: New malignancy criteria. Langenbecks Arch Surg. 2012;397:239-46. 
63. Papathomas TG, Oudijk L, Persu A, Gill AJ, van Nederveen F, Tischler AS, Tissier F, Volante M, Matias-Guiu X, Smid M, Favier J, Rapizzi E, Libe R, Currás-Freixes M, Aydin S, Huynh T, Lichtenauer U, van Berkel A, Canu L, Domingues R, CliftonBligh RJ, Bialas M, Vikkula M, Baretton G, Papotti M, Nesi G, Badoual C, Pacak K, Eisenhofer G, Timmers HJ, Beuschlein F, Bertherat J, Mannelli M, Robledo M, Gimenez-Roqueplo AP, Dinjens WN, Korpershoek E, de Krijger RR. SDHB/ SDHA immunohistochemistry in pheochromocytomas and paragangliomas: Amulticenter interobserver variation analysis using virtual microscopy: A multinational Study of the European Network for the Study of Adrenal Tumors(ENS@T). Mod Pathol. 2015;28:807-21.

64. Gopalan V, Smith RA, Lam AK. Downregulation of microRNA-498 in colorectal cancers and its cellular effects. Exp Cell Res. 2015;330:423-28.

65. Amin M, Lam AK. Current perspectives of mi-RNA in oesophageal adenocarcinoma: Roles in predicting carcinogenesis, progression and values in clinical management. Exp Mol Pathol. 2015;98:411-18.

66. Gopalan V, Pillai S, Ebrahimi F, Salajegheh A, Lam TC, Le TK, Langsford N, Ho YH, Smith RA, Lam AK. Regulation of microRNA-1288 in colorectal cancer: Altered expression and its clinicopathological significance. Mol Carcinog. 2014; 53: E36-E44
67. Ebrahimi F, Gopalan V, Smith RA, Lam AK. miR-126 in human cancers: Clinical roles and current perspectives. Exp Mol Pathol. 2014;96:98-107.

68. MaroofH, Salajegheh A, Smith RA, Lam AK. Role of microRNA-34 family in cancer with particular reference to cancer angiogenesis. Exp Mol Pathol. 2014; 97: 298-304.

69. Vosgha H, Salajegheh A, Smith RA, Lam AK. The Important Roles of miR-205 in normal physiology, cancers and as a potential therapeutic target. Curr Cancer Drug Targets. 2014; 14: 621-37.

70. Maroof H, Salajegheh A, Smith RA, Lam AK. MicroRNA-34 family, mechanisms of action in cancer: A review. Curr Cancer Drug Targets. 2014;14:737-51.

71. Castro-Vega LJ, Letouzé E, Burnichon N, Buffet A, Disderot PH, Khalifa E, Loriot C, Elarouci N, Morin A, Menara M, LepoutreLussey C, Badoual C, Sibony M, Dousset B, Libé R, Zinzindohoue F, Plouin PF, Bertherat J, Amar L, de Reyniès A, Favier J, GimenezRoqueplo AP. Multi-omics analysis defines core genomic alterations in pheochromocytomas and paragangliomas. Nat Commun. 2015;6:6044.

72. Patterson E, Webb R, Weisbrod A, Bian B, He M, Zhang L, Holloway AK, KrishnaR, Nilubol N, Pacak K, Kebebew E. The microRNA expression changes associated with malignancy and SDHB mutation in pheochromocytoma. Endocr Relat Cancer. 2012;19:157-66. 